\title{
Soil heterogeneity after recultivation: ecological aspect
}

\author{
Galina A. Zadorozhnaya ${ }^{1 *}$, Kateryna V. Andrusevych ${ }^{2,3}$, Olexander V. Zhukov ${ }^{4}$ \\ ${ }^{1}$ Department of Human and Animal Physiology, Oles Honchar Dnipro National University, Gagarin av., 72 , \\ Dnipro, 49010, Ukraine \\ ${ }^{2}$ Dnipropetrovsk State Agrarian and Economic University, Sergei Efremov st., 25, Dnipro, 49600, Ukraine \\ ${ }^{3}$ Dnieper-Orilskiy' Nature Reserve, 52030 Obukhovka, Dniprovsk district, Dnipropetrovsk region, Ukraine \\ ${ }^{4}$ Department of Zoology and Ecology, Oles Honchar Dnipro National University, Gagarin av., 72, \\ Dnipro, 49010, Ukraine
}

\begin{abstract}
Zadorozhnaya, G.A., Andrusevych, K.V., Zhukov, O.V., 2018. Soil heterogeneity after recultivation: ecological aspect. Folia Oecologica, 45: 46-52.

The study subject was the soil heterogeneity at a recultivation site Nikopol manganese-ore basin (Pokrov, Ukraine). The soils at the locality are sod lithogenic soils developed on gray-green clays. The study ran by applying soil penetration resistance indices. The penetration resistance was measured across a regular grid of $7 \times 15$ points $(21 \times 45 \mathrm{~m})$. The distance between the measurement points was $3 \mathrm{~m}$. The parameters were recorded at every $5 \mathrm{~cm}$ to a depth of $50 \mathrm{~cm}$. The environmental parameters were determined by phytoindication. Geostatistical analysis showed the average level of spatial dependence of soil penetration resistance. According to the features of the profile variation in penetration resistance with the depth, the measurement points have been divided into three clusters. The clusters formed morphologically homogeneous soil areas. These areas significantly differed in their soil acidity and in nitrogen content in soil.
\end{abstract}

\section{Key words}

geostatistics, phytoindication, recultivation, soil heterogeneity, soil penetration resistance

\section{Introduction}

The south of the Dnipropetrovsk region includes one of the largest manganese-ore basins in Ukraine. The developments there are open-cut. The soil types predominant on the lands of the region are ordinary chernozem (Calcic Chernozem) soil and southern chernozem predominate. These soils are fertile and contain a thick humus horizon. The open-cut mining operations result in complete destruction of soils and vegetation, accompanied by formation of dumps from mixtures of overburden rocks. The technology of overburden management involves their storage in pits, subsequent leveling and creation of artificial soil-like bodies. These are created using two technologies: the first involving application of a fertile layer and the second eliminating such application. Further use of such lands is an important national economic and scientific issue.

Increased heterogeneity is one of the features characteristic recultivated soils (PARAČKOVA and ZAUJEC, 2001; ZHUKov et al., 2012). There are several reasons for technical soils heterogeneity. First, it is the heterogeneity of the soil body, being its immanent feature (DrAY et al., 2006; Diacono et al., 2013; JimENEZ et al., 2014; BAVEYE and LABA, 2015). It represents a necessary condition for emerging and evolving biological diversity (MOUILLOT et al., 2006; BRIND’Amour et al., 2011). Such heterogeneity 
develops as a self-organizing system enhancing over time (Rode, 1984; Cambardella et al., 1994). In addition to the natural heterogeneity of technical soil, the artificial heterogeneity is also attributable to technical soil. The artificial heterogeneity is created when the substrates are dumped during the technical stage of recultivation. This process runs on certain historical backgrounds and the heterogeneity is leveled over time with the soil-forming process (KrEMER, 1970; BARONI et al., 2013). The specific nature of these processes in technical soils remains poorly explored. The reason for this is a long time necessary for formation of morphologically well-developed soil (TravleEv et al., 2008). However, the reason does not reduce the relevance of such studies. The soil-forming process is of great importance for determining the degree of young soil involvement in the ecosystem vital processes (ANAND et al., 2002).

It is well-known that the structure of chernozem depends on the variability of external factors (ZHUKOV et al., 2017, ZADOROZHNA, 2017). It has been revealed that morphologically different soil parts are closely connected with the parameters of the external environment (ZADOROZHNA, 2017). In chernozem the connection is evident based on a change in the acidity of the soil solution, salts, carbonate compounds, temperature and soil moisture. The structure of chernozem also depends significantly on its vegetation cover structure. The ecological features of species are different in the areas with different structure (ZADOROZHNA, 2017). In the works referred, the morphological heterogeneity of chernozem was determined by measuring the soil penetration resistance. The parameters of external environment have been established using the method for phytoindication (Didukh, 2011, 2012; MatveEv, 2003).

The work's objective was to evaluate the connection between the soil heterogeneity after recultivation and the environmental conditions applying the phytoindication method.

\section{Materials and methods}

Data collection was carried out at the recultivation site situated in the Nikopol manganese-ore basin. The study subject was the local sod and lithogenic soil developed on gray-green clays. The soil has been named according to L.V. Yeterevska (YeTEREvsKA et al., 2012). The gray-green clays have been brought to the surface from a depth of 12-47 m. These substrates are not phytotoxic (Demidov et al., 2013). At the moment, the vegetation is represented by a bean and cereal mixture. The time of staying on the daylight is about 40 years.

The study was conducted on a regular grid. The distance between the measurement points was $3 \mathrm{~m}$. The test polygon consisted of 7 transects of each with 15 points $(21 \times 45 \mathrm{~m})$.

The soil heterogeneity is determined through its penetration resistance indices (BUSSOHER et al., 2000;
ZAHRADNIČEK et al., 2001; HERrick and JONeS, 2002; LOWERY and Morrison, 2002; CASTRIGNANO et al., 2004; ZhuKov and ZADOROZHNAYA, 2016). The tool used in our study was an Eijkelkamp hand penetrometer with an average measurement error of $\pm 8 \%$. The data were recorded every $5 \mathrm{~cm}$. The measurement depth was $50 \mathrm{~cm}$ (10 penetration resistance indices in each of 105 points of the polygon).

To determine the external parameters, the phytoindication method was used (DIDUKH, 2011, 2012; Matveev, 2003; Nazarenko, 2016; Tarasov, 2005). At each point of the test site, the vegetation was described: the species composition and projective cover of each species. Through the use of (DIDUKH, 2011, 2012), the environmental parameters were determined: soil water regime (Hd), variability of damping (ffl), soil acidity $(\mathrm{Rc})$, total salt regime $(\mathrm{Sl})$, carbonate content in soil $(\mathrm{Ca})$, nitrogen content in soil $(\mathrm{Nt})$, soil aeration $(\mathrm{Ae})$, thermal climate $(\mathrm{Tm})$, humidity $(\mathrm{Om})$, continentality of climate $(\mathrm{Kn})$, cryo-climate $(\mathrm{Cr})$, and light $(\mathrm{Lc})$.

Aggregate figures $(x)$, standard error (SE), 95\% confidence interval and coefficient of variation $(\mathrm{CV}$, $\%$ ) were estimated using descriptive statistics. A geostatistical analysis of data was used to determine the level of spatial dependence of the penetration resistance indices (Veronese Junior et al., 2006; Webster and Oliver, 2007; Valbuena Calderon et al., 2008). The spatial dependence level (SDL, spatial relationship) was calculated using the formula:

$$
S D L=\frac{C_{0}}{C_{0}+C_{1}} \times 100,
$$

where $C_{0}$ is the nugget-effect, $C_{I}$ is a sill. The SDL level of $0-25 \%$ indicates high spatial dependence. If it varies from 26 to $75 \%$, then the observed dependence is average. SDL values above $75 \%$ are indicative for a weak spatial dependence in data (WEBSTER and OLIVER, 2007).

The $C_{0}, C_{1}$ indices and the range $(\mathrm{R})$ were obtained on the basis of simulations of exponential variograms expressing the spatial variability of soil penetration resistance (LEGENDRE and Fortin, 1989; WebSTER and OLIVER, 2007).

\section{Results}

Penetration resistance is an essential soil characteristic (BAJla and MinariK, 2003; Bolenius et al., 2006). Variation in penetration resistance is associated with changes in many soil properties, such as humidity, granulometric and aggregate composition, the amount of soil organic matter, and similar. (VACHEL and EHRLICH, 1988; Young et al., 2000; GrunwaLd et al., 2001; VANAGS et al., 2004; TopP et al., 2003; BaJla and MinariK, 2003; Bolenius et al., 2006; Medvedev, 2010; Zhukov et al., 2014). All these properties are important for soil fertility. The results of measuring soil penetration resistance stipulate the conditions for the growth of plant root systems 
(Lipiec and Hatano, 2003; Hamza and Anderson, 2005; Medvedev, 2010). This represents a new methodical approach. The measurement of spatial variation in soil penetration resistance gives a three-dimensional mapping of the soil body state (Zhukov and KunAKH, 2011; Cecilia et al., 2012; ZhuKov and ZADOROZHNAYA, 2015; Zhukov et al., 2017).

The recultivated soil penetration resistance increases
Geostatistical analysis showed an average level of spatial dependence of the data. This is evidenced by SDL values (Table 1).

The parameter expressing soil masses interactions is the radius of influence $(\mathrm{R})$. This parameter shows how far the impact is spread from the source point (VERONESE Junior et al., 2006; Webster and Oliver, 2007; VAlbuena Calderon et al., 2008). $\mathrm{R}$ is the smallest in the layers

Table 1. Descriptive statistics and spatial variation parameters of soil penetration resistance

\begin{tabular}{cccccccc}
\hline \multirow{2}{*}{ Layers depth $(\mathrm{cm})$} & $\mathrm{x} \pm \mathrm{SE}(\mathrm{MPa})$ & \multicolumn{2}{c}{ Confidence interval } & & CV $(\%)$ & SDL $(\%)$ & $\mathrm{R}(\mathrm{m})$ \\
\cline { 3 - 5 } & & $-0.95 \%$ & $+0.95 \%$ & & & & \\
\hline $0-5$ & $2.16 \pm 0.82$ & 2.00 & 2.32 & 38.8 & 32.84 & 6.05 \\
$5-10$ & $3.63 \pm 0.18$ & 3.26 & 4.01 & 53.5 & 55.87 & 8.24 \\
$10-15$ & $5.25 \pm 0.21$ & 4.83 & 5.66 & 41.2 & 36.92 & 5.92 \\
$15-20$ & $6.28 \pm 0.22$ & 5.85 & 6.71 & 35.4 & 68.77 & 4.31 \\
$20-25$ & $6.80 \pm 0.21$ & 6.38 & 7.21 & 31.7 & 71.74 & 4.31 \\
$25-30$ & $7.35 \pm 0.23$ & 6.89 & 7.80 & 31.9 & 72.34 & 12.23 \\
$30-35$ & $7.67 \pm 0.25$ & 7.17 & 8.17 & 33.8 & 50.84 & 10.70 \\
$35-40$ & $8.21 \pm 0.28$ & 7.67 & 8.76 & 34.5 & 72.34 & 12.23 \\
$40-45$ & $8.81 \pm 0.30$ & 8.22 & 9.41 & 35.0 & 37.89 & 15.89 \\
$45-50$ & $9.33 \pm 0.31$ & 8.70 & 9.95 & 34.5 & 42.99 & 15.48 \\
\hline
\end{tabular}

$\mathrm{x}$, mean (MPa); SE, standard error; CV, coefficient of variation (\%); SDL, spatial dependence level (\%); R, range (m).

gradually with the depth. The smallest absolute values are observed on the surface $(2.16 \pm 0.82 \mathrm{MPa})$. The highest penetration resistance values $(9.33 \pm 0.31 \mathrm{MPa})$ were detected at the deepest studied layer $(45-50 \mathrm{~cm})$. The variation coefficient ranged from $31.7-53.5 \%$. of $15-20$ and $20-25 \mathrm{~cm}(4.31 \mathrm{~m})$. The greatest radius of influence in the layer is $40-45 \mathrm{~cm}(15.89 \mathrm{~m})$.

The data clustering has resulted in allocating three clusters differing in the form of their vertical soil penetration resistance vector (Fig. 1).

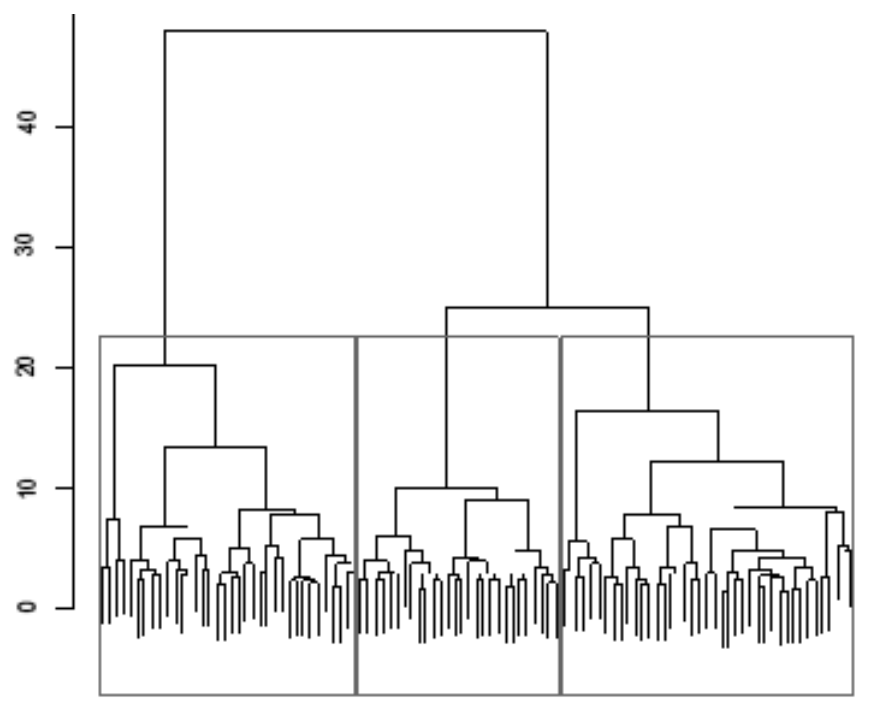

Fig. 1. Hierarchical dendrogram expressing soil penetration resistance according to the results of cluster analysis. Rectangles indicate the volume of clusters. 
The averaged cluster profiles differ in the intensity of penetration resistance increase with depth (Fig. 2). The most sharp increase in penetration resistance has been noticed in the first cluster. The difference in values is about $11 \mathrm{MPa}$. The second cluster is characterized by a relatively conditions for plant growth. The analysis of vegetation cover has also shown some other distinctive features of the clusters.

To determine the characteristics of the environment, the phytoindication method was applied. It is simple and gives

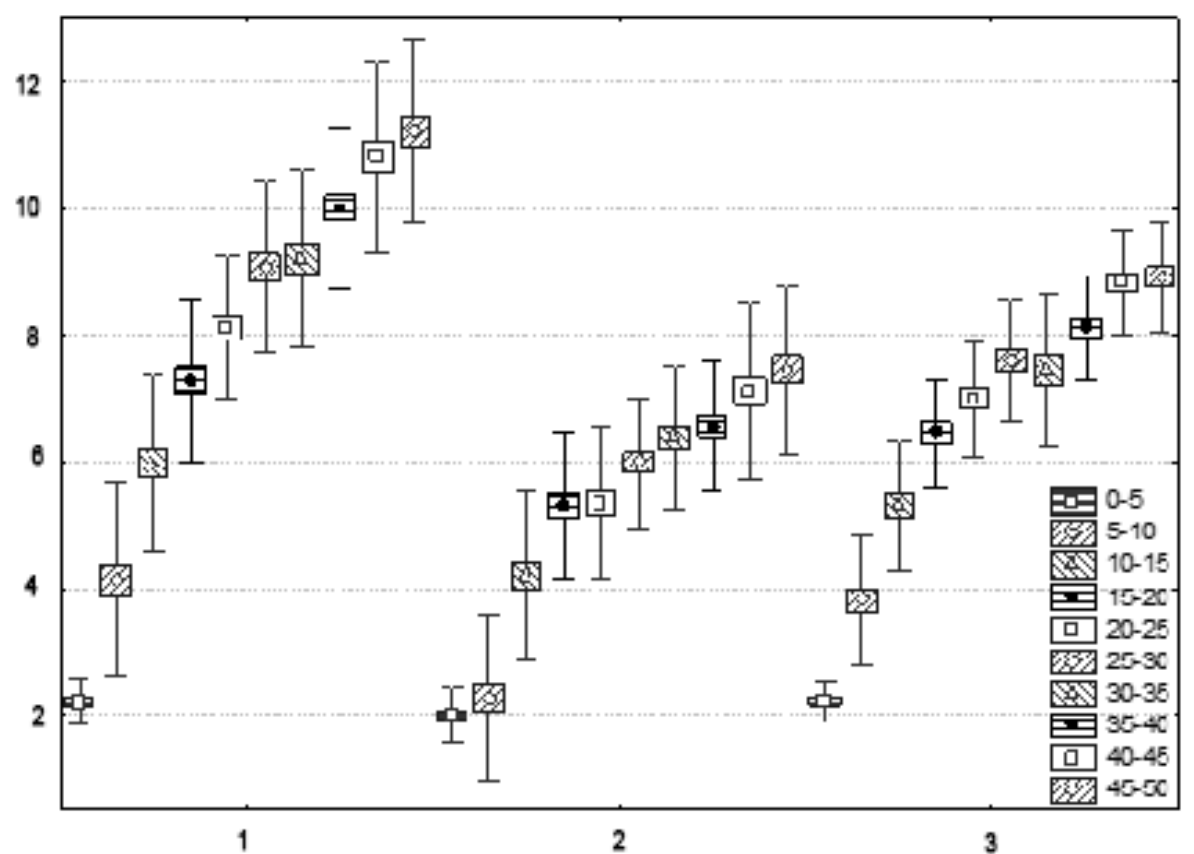

Fig. 2. Changes in soil penetration resistance values along the soil profile in different clusters. On the abscissa the cluster numbers are shown, on the ordinate the penetration resistance of the soil is indicated, MPa.

low penetration resistance in the $5-10 \mathrm{~cm}$ layer (about 2 $\mathrm{MPa}$ ). Below $20 \mathrm{~cm}$, the increase in penetration resistance is insignificant. The third cluster occupies an intermediate position. In this cluster, a drastic increase in values from 0 to $30 \mathrm{~cm}$ is replaced by a less intense growth.

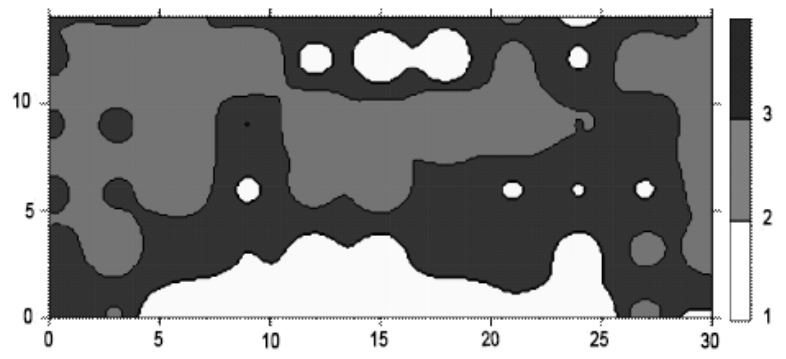

Fig. 3. Spatial patterns of soil penetration resistance clusters.

The distribution of clusters in a two-dimensional plane is shown in Figure 3. The points with similar profiles are marked in one color. They are grouped in areas with similar reliable results (ZHuKov, 2015). Its essence is in the use of vegetation as an indicator for soil and climatic features of the terrain (Diduch, 2011). Thus, each point of the test site were characterized. Differences in clusters by external features were detected. To achieve this, discriminant analysis was used. The scales of soil solution acidity and of the nitrogen assimilable forms content have statistically significant coefficient of discrimination (Table 2).

The cluster 1 has the lowest content of nitrogen assimilable in soil and the increased acidity of the soil solution (Fig. 4). In this cluster, penetration resistance reaches the highest values (Fig. 2).

Clusters two and three are similar in their properties. A distinctive feature of the second cluster sections is the lowest value of penetration resistance in deep layers. The soil acidity and the nitrogen content are not significantly different from the values detected for the third cluster. The cluster three is characterized by the highest content of nitrogen forms assimilable in the soil. Also, this area is characterized by a wide range of acidity values of the soil solution.

The dominant plants of the experimental site are Bromus squarrosus (L.), Seseli campestre (Besser.), Elytrigia intermedia (Host) Nevski, Falcaria vulgaris (Bernh.), Medicago sativa (L.), Consolida regalis (Gray). 
Table 2. General results of discriminant analysis of vegetation data for clusters

\begin{tabular}{cccc}
\hline $\begin{array}{c}\text { Phytoindication } \\
\text { scales }\end{array}$ & $\begin{array}{c}\text { Wilks' } \\
\text { lambda }\end{array}$ & F-test & $p$-level \\
\hline Hd & 0.45 & 0.89 & 0.41 \\
$\mathrm{ffl}$ & 0.46 & 1.59 & 0.21 \\
$\mathrm{Rc}$ & $\mathbf{0 . 5 1}$ & $\mathbf{6 . 6 4}$ & $\mathbf{0 . 0 0}$ \\
$\mathrm{Sl}$ & 0.44 & 0.14 & 0.87 \\
$\mathrm{Ca}$ & 0.45 & 0.70 & 0.50 \\
$\mathrm{Nt}$ & $\mathbf{0 . 5 6}$ & $\mathbf{1 2 . 0 1}$ & $\mathbf{0 . 0 0}$ \\
$\mathrm{Ae}$ & 0.45 & 1.01 & 0.37 \\
$\mathrm{Tm}$ & 0.45 & 0.72 & 0.49 \\
$\mathrm{Om}$ & 0.45 & 0.95 & 0.39 \\
$\mathrm{Kn}$ & 0.45 & 0.60 & 0.55 \\
$\mathrm{Cr}$ & 0.45 & 1.03 & 0.36 \\
$\mathrm{Lc}$ & 0.46 & 1.60 & 0.21 \\
\hline
\end{tabular}

Hd, soil water regime; ffl, variability of damping; Rc, soil acidity; Sl, total salt regime; $\mathrm{Ca}$, carbonate content in soil; $\mathrm{Nt}$, nitrogen content in soil; Ae, soil aeration; Tm, thermal climate; Om, humidity; $\mathrm{Kn}$, continentality of climate; $\mathrm{Cr}$, cryo-climate; Lc, light. Statistically significant correlations $(\mathrm{p}<0.05)$ are shown in bold.
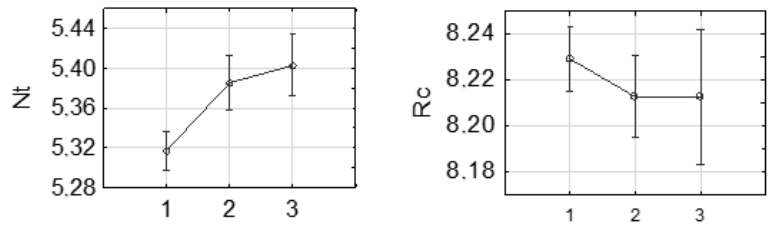

Fig. 4. Phytoindication values for nitrogen content in soil and soil acidity expressed by clusters. The abscissa represents value of the corresponding scale, the ordinate axis represents numbers of clusters indicated.

These plants have been registered at all points of the studied site. However, only on the territory of cluster 1 there have been registered Tragopogon major (Jacq.), Senecio jacobaea (L.), Atriplex micrantha (C. A. Mey), Medicago romanica (Prod.) and Festuca valesiaca (Gaud.). The territory of cluster 2 differs by the presence of Centaurea diffusa (Lam.). Only the territory of cluster 3 displays registered Artemisia absinthium (L.) and Chondrilla juncea (L.).

\section{Discussion}

The results of this study show that the heterogeneity of recultivated lands is not accidental. The studied territory has been distinctly divided into sections with different conditions. These conditions are expressed by different depth-related increase rates in the soil penetration resistance. The plants respond to a variety of conditions across the area. The regularities in the species distribution indicate the existence of more differences among the selected areas. These differences are the soil solution acidity and the presence of nitrogen nutrition for plants. The areas with increased penetration resistance are characterized by the lowest level of assimilable forms of nitrogen and by increased acidity. Extremely low penetration resistance indicators are common for the territories with higher nitrogen contents. The mechanism of the structure formation is probably the vital activity of plants. Roots influence the soil properties (BREEMEN and FInZI, 1998). This effect can be either mechanical or chemical. By aspirating moisture, vegetation has an effect on both soil physical properties and its chemical composition (ZAHRADNIČEK et al., 2001; ToPP et al., 2003; Demidov et al., 2013; TuŽInskÝ et al., 2017). Plants use soil substances for their metabolism and release the products of vital activity into the soil. When dying, the parts of the root systems raise the content of organic matter. In places with a lower penetration resistance value, the amount of organic matter increases. The chemical composition and physical state of the substrate varies, and the heterogeneity increases (Heuvelink and Webster, 2001; Medvedev, 2010; RAD et al., 2017).

After forty years of recultivation, the heterogeneity of the bulk substrate shows certain regularities. They are expressed in the connection between morphological features, with soil and climatic conditions. These changes in gray-green clay have been initiated and driven by the soil formation process. The substrate is evolved under impacts from external factors (CAMBARDELLA et al., 1994; HeuVELINK and Webster, 2001; ANAND et al., 2002, ZhuKov, 2015; ZAdorozhnA, 2017; Polláková et al., 2017). The acidity and the amount of nitrogen in soil were probably the limiting factors for plants at the time of the experiment. The changes in soil penetration resistance are a fundamental diagnostic feature allowing diverse soil areas to allocate. These areas represent separate morphological formations. Their independence is confirmed by distinctive features. These features differ in their nature, but they can reliably distinguish the areas allocated.

\section{Conclusions}

The recultivated soil penetration resistance increases with depth. The highest variation was observed in the data assembled from the layer of 5-10 $\mathrm{cm}$ below the surface. The spatial dependence of penetration resistance for the technical soil developed on gray-green clay has been assessed as average, with the influence radius varying between $4.31-15.89 \mathrm{~m}$.

The performed cluster analysis identified three types of investigated measurement points. Differing in the nature of the penetration resistance variation with depth. Similar sites have been clustered and they form the spatial structure of the test site. The clusters reliably significantly differ from each other in soil solution acidity and in the content of the assimilated nitrogen forms. 
Penetration resistance is a satisfactory diagnostic feature for soils. Penetration resistance measurement makes it possible to identify the elements of soil heterogeneity.

\section{References}

Anand, M., Tucker, B.C., Desrochers, R., 2002. Ecological monitoring of terrestrial ecosystem recovery from manmade perturbation: assessing community complexity. In Proceedings of the 10th International conference on modelling, monitoring and management of air pollution. Segovia, Spain, July 1-3, 2002. Southampton: WIT Press, p. 341-350.

Bajla, B.C., Minarik, J., 2003. Návrh metódy namerania okamžitej vlhkosti pôdy pri hrote penetrometra [Proposal of a method for measuring the instantaneous moisture content in soil proximate to the tip of penetrometer]. Acta Technologica Agriculturae, 6 (4): 93-96.

Baroni, G., Ortuani, B., Facchi, A., Gandolfi, C., 2013. The role of vegetation and soil properties on the spatiotemporal variability of the surface soil moisture in a maize-cropped field. Journal of Hydrology, 489: 148159.

Baveye, P.C., LabA, M., 2015. Moving away from the geostatistical lamppost: why, where, and how does the spatial heterogeneity of soils matter? Ecological Modelling, 298: 24-38.

Bolenius, E., Bölenius, E., Rogstrand, G., Thylén L., 2006. On-the-go measurements of soil penetration resistance on a Swedish EutricCambisol. In Proceedings of the International Soil Tillage Research Organisation (ISTRO), 17th Triennial conference. Kiel, Germany, August 28-September 3, 2006. Kiel: ISTRO, p. 867-870.

Breemen, N., FinZI, A.C., 1998. Plant-soil interactions: ecological aspects and evolutionary implications. Biogeochemistry, 42: 1-19.

Brind'Amour, A., Boisclair, D., Dray, S., Legendre, P., 2011. Relationships between species feeding traits and environmental conditions in fish communities: a threematrix approach. Ecological Applications, 21 (2): 363 377.

Bussoher, W.J., Frederick, J.R., BANER, B.J., 2000. Timing effects of deep tillage on penetration resistance and wheat and soybean yield. Soil Science Society of America Journal, 64 (3): 999-1003.

Cambardella, C.A., Moorman, T.B., Novak, J.M., Parkin, T.B., 1994. Field scale variability of soil properties in central Iowa soils. Soil Science Society of America Journal, 58: 1501-1511.

Castrignano, A.D., De Giorgio, Fornaro, F, Vonella, A.V., 2004. 3D spatial variation of the soil impedance as affected by soil tillage. In Conserving soil and water for society: sharing solutions. Proceedings the 13th International Soil Conservation Organisation Conference. Brisbane, 4-9th July. Paper no 744, 5p.

Cecilia, M., Jesus, H. C., Cortes, C.A., 2012. Soil penetration resistance analysis by multivariate and geostatistical methods. Engenharia Agricola, Jaboticabal, 32: 91-101.

Demidov, A.A., Kobets, A.S., Gritsan, Y.I., Zukov, A.V., 2013. Prostranstvennaya agroekologiya i rekultivatsiya zemel [Spatial agroecology and land reclamation: monograph]. Dnepropetrovsk: Svidler A.L. 560 p.

Diacono, M., Benedetto, D., Castrignanò, A., Rubinoa, P., Vitti, C., Abdelrahman, H.M., Sollitto, D., Cocozza, C., Ventrella, D., 2013. A combined approach of geostatistics and geographical clustering for delineating homogeneous zones in a durum wheat field in organic farming. NJAS - Wageningen Journal of Life Sciences, 64-65: 47-57.

Didukn,YA.P., 2011. The ecological scales for the species of Ukrainian flora and their use in synphytoindication. Kyiv: Phytosociocentre. $176 \mathrm{p}$.

Didukh, YA.P., 2012. Osnovy bioindykatsii [Fundamentals of bioindication]. Kyiv: Naukova dumka. 344 p.

Dray, S., Legendre, P., Peres-Neto, P., 2006. Spatial modelling: a comprehensive framework for principal coordinate analysis of neighbours matrices (PCNM). Ecological Modelling, 196: 483-493.

Grunwald, S., McSweeney, K., Rooney, D.J., Lowery B., 2001. Soil layer models created with profile cone penetrometer data. Geoderma, 1103 (1-2): 181-201.

Hamza, M.A., Anderson, W.K., 2001. Soil compaction in cropping systems: a review of the nature, causes and possible solutions. Soil and Tillage Research, 82 (2): 121-145.

Herrick, J.E., Jones, T.L., 2002. A dynamic cone penetrometer for measuring soil penetration resistance. Soil Science Society of America Journal, 66: 1320-1324.

HeuvelinK, G.B.M., Webster, R., 2001. Modelling soil variation: past, present, and future. Geoderma, 100: 269 301.

Jiménez Juan, J., Decaëns, T., Lavelle, P., Rossi, J., 2014. Dissecting the multi-scale spatial relationship of earthworm assemblages with soil environmental variability. BMC Ecology, 14: 26-45.

Kremer, A.M., 1970. Neodnorodnosti pochvennogo pokrova kak samoorganizuyushchiesya sistemy [The heterogeneity of the soil cover as self-organizing systems]. In Zakonomernosti prostranstvennogo varirovaniya svoystv pochv $i$ informatsionno-statisticheskie metody ih izucheniya. Moskva, p. 68-80.

Legendre, P., Fortin, M.J., 1989. Spatial pattern and ecological analysis. Vegetatio, 80: 107-138.

LiPIES, J., Hatano, H., 2003. Quantification of compaction effects on soil physical properties and crop growth. Geoderma, 116 (1-2): 107-136.

LOWEry, B., Morrison, J.E., 2002. Soil penetrometers and penetrability. In Methods of soil analysis. Part 4, Physical methods. Soil Science Society of America book series, 5. Madison: Soil Science Society of America, p. 363-388.

MatveEv, N.M., 2003. Optimizatsiya sistemyi ekomorf rasteniy A.L. Belgarda $\mathrm{v}$ tselyah indikatsii ekotopa $\mathrm{i}$ biotopa [Optimization of the system of plant ecomorphs Bel'gard for the purpose of indicating the ecotope and biotope]. Visnyk of Dnipropetrovsk University: Biology, Ecology, 11 (2): 105-113.

Medvedev, V.V., 2010. Neodnorodnost kak zakonomernoe proyavlenie gorizontalnoy strukturyi pochvennogo pokrova [Heterogeneity as natural display of horizontal structure of a soil cover]. Gruntoznavstvo, 11 (1-2): 6-15.

Mouillot, D., Spatharis, S., Reizopoulou, S. T., Laugier, L., Sabetta, A., Basset, T., Do Chi., T., 2006. Alternatives to taxonomic-based approaches to assess changes in 
transitional water communities. Aquatic Conservation: Marine and Freshwater Ecosystems, 16: 469-482.

NAZARENKo, N.N., 2016. Tsenomorfyi kak fitoindikatoryi biotopov [Coenomorphs as phytometers of biotopes]. Visnyk of Dnipropetrovsk University: Biology, Ecology, 24 (1): 8-14.

ParačKova, A. Zaujec, A., 2001. Evaluation of human impacts on soils on the Borska lowland. Ekológia (Bratislava), 20 (3): 299-304.

Polláková, N., ŠimanskÝ, V., JonCZAK, J., 2017. Characteristics of physical properties in soil profiles under selected introduced trees in the Nature Reserve Arboretum Mlyňany, Slovakia. Folia Oecologica, 44: $78-86$.

RAD, J.E, VAladi, G., Zargaran, M.R., 2017. Effect of manmade disturbances on understory plant richness of oak forests in Iran. Folia Oecologica, 44: 61-68.

Rode, A.A., 1984. Genezis pochv i sovremennyie protsessyi pochvoobrazovaniya [Genesis of soils and modern soil formation processes]. Moskva: Nauka. $256 \mathrm{p}$.

Tarasov, V.V., 2005. Flora Dnipropetrovskoi i Zaporizkoi oblastei [Flora of the Dnipropetrovsk and Zaporizhia regions]. Lira: DNU. 276 p.

TuŽINSKÝ, L., BublineC, E., TuŽInskÝ, M., 2017. Development of soil water regime under spruce stands. Folia Oecologica, 44: 46-53.

Topp, G.C., Lapena, D.R., Edwards, M.J., Young, G.D., 2003. Laboratory calibration, in-field validation and use of a soil penetrometer measuring cone resistance and water content. Vadose Zone, 2: 633-641.

Travleev, A.P., Belova, N.A. Balalayev, A.K., 2008. Ekologiya pochvoobrazovaniya lesnyih chernozemov [Ecology of the forest chernozems formation]. Gruntiznavstvo, 9 (1-2): 19-29.

VAChel, J., Ehrlich, P., 1988. Využití penetrometrické metody měrení pevnosti zemin $\mathrm{v}$ průzkumech pro odvodnění [Using penetrometry in assessment of soil resistance in surveys performed for draining purposes]. Vědecké práce Výzkumného ústavu pro zúrodněni zemédèlských pưd, 5: 131-140.

Valbuena Calderon, C.A., Martines, L.J., Giraldo Henao, R., 2008. Variabilidad especial del suelo y surelacion con el rendimiento de mango (Mangifera indica L.) [Spatial variability of soil properties and yield relationship in a mango crop (Mangifera indica L.)]. Revista Brasileira de Fruticultura, Jaboticabal, 30 (4): 1146-1151.

Vanags, C., Minasny, B., McBratney, A.B., 2004. The dynamic penetrometer for assessment of soil mechanical resistance. In Supersoil 2004. Proceeding of the 3th Australian New Zealand Conference. [cit. 2017-9-12]. http://www.regional.org.au/au/asssi/supersoil2004/s14/ poster/1565 vanagsc.htm

Verones Junior, V., Carvalho, M.P., Dafonte, J., Freddi, O.S., Vidal Vazquez, E. Ingaramo, O.E., 2006. Spatial variability of soil water content and mechanical resistance of Brazilian ferralsol. Soil and Tillage Research, 85 (12): $166-177$.

Webster, R., Oliver, M.A., 2007. Geostatistics for Environmental Scientist. Chichester: John Wiley \& Sons. $318 \mathrm{p}$.

Yeterevska, L.V., Stammerer, G.F., Kanash A.P., 2008. Rekultyvovani grunty pidkhody do klasyfikatsii i systematyky [Recultivated soils approaches to classification and taxonomy]. Gruntiznavstvo, 9 (3-4): $147-150 \mathrm{p}$.

Young, G.D., Adams, B.A., Topp, G.C., 2000. A portable data collection system for simultaneous cone penetrometer force and volumetric soil water content measurements. Journal of Soil Science, 80: 23-31.

ZadorozhnA, G.O., 2017. Soil ecomorphs as form of adaptation to the conditions of biogeocenosis. Scientific Bulletin Eastern National University named after Lesya Ukrainian. Series: Biological Sciences, 17 (342): 94-102.

Zahradniček, J., Beran, P., PulkrabeK, J., Svachula, B., FamĚra, O., Sroller, J., Chochola, J., 2001. The effect of physical soil properties on metabolism and technological quality of sugar beet. Rostlinná Výroba, 47 (1): $23-27$.

ZhuKov, A., ZadorozhnaYA, G., 2016. Spatial heterogeneity of mechanical impedance of atypical chernozem: the ecological aproach. Ekológia (Bratislava), 35 (3): 263278.

Zhukov, A.O., Zadorozhna, G.O., Maslikova, K.P., ANDruSEVICH, K.V., LyadSKA, I.V., 2017. Ekolohiya tekhnozemiv [Ecology of technosems]. Dnepr: Zhurfond. $444 \mathrm{p}$.

Zhuкоv, A.V., 2015. Fitoindykatsiine otsiniuvannia vymiriv, oderzhanykh za dopomohoiu bahatovymirnoho shkaliuvannia struktury roslynnoho uhrupovannia [Phytoindicative estimation of measurements obtained with multidimensional scaling of the plant community structure]. Chornomorskyi Botanichnyi Zhurnal, 1 (11): 84-95.

Zhukov, A.V., Zadorojhna, G.O., Lyadskaya, I.V., 2014. Fizychni vlastyvosti rekultozemiv Nikopolskoho marhantsevorudnoho basseinu [Physical properties of the rekultozems of the Nikopolsky manganese-ore basin]. Pytannia Stepovoho Lisoznavstva ta Lisovoi Rekultyvatsii Zemel, 43: 93-102.

Zhukov, A.V., Zadorozhna, G.A., 2016. Prostranstvennovremennaya dinamika tverdosti rekultivirovannyih pochv, sformirovannyih $\mathrm{v}$ rezultate dobyichi poleznyih iskopaemyih otkryityim sposobom [Spatio-temporal dynamics of the recultivated soils penetration resistance formed after open mining]. Visnyk of Dnipropetrovsk University: Biology, Ecology, 24 (2): 324-331.

Zhukov, A.V., ZadorozhnaYA, G.A., 2015. Otsenka ecomorphogenesa pedozema y chernozema obyknovennoho na osnove pokazatelei tverdosty [Pedozem and chernozem ecomorphogenesis assessment by soil penetration resistance data]. Ahrokhimiya $i$ Gruntoznavstvo, 84: 72-80.

Zhukov, A.V., Zadorozhnaya, G.A., Andrusevich, K.V., 2012. Ekolohicheskiie kharakteristiki pedonov diernovolitohiennykh pochv na lesakh [Ecological characteristics of the pedons of soddy-lithogenic soils on loess]. Visnyk $D D A U, 2: 9-11$.

ZhuKov, O.V., KunAh, O.M., 2011. Tverdost dernovolitogennyih pochv na lessovidnyih suglinkah [Penetration resistance of sod-lithogenic soils on loesslike loams]. Visnyk DDAU, 1: 63-69.

Received November 4, 2017 Accepted April 25, 2018 